\title{
Alterations in patterns of excretion and other metabolic functions in developing fish embryos exposed to benzo(a)pyrene
}

\author{
R. M. Kocan \& M. L. Landolt \\ University of Washington, School of Fisheries, WH-10; Seattle, Washington 98195, USA
}

\begin{abstract}
Steelhead trout (Salmo gairdneri) embryos were used as a model to study some of the physiological and biochemical changes which occur following exposure to sublethal levels of benzo(a)pyrene B(a)P, a known environmental contaminant. Embryos were exposed to B(a)P on day 1,15 , or 25 post fertilization, corresponding to the pre-blastula, eyed stage and late organogenesis stage of development. These times were chosen to determine whether the age of the embryo at the time of exposure influenced their response to this model compound. The changes which were observed were related to the age of the embryo at the time of exposure but not to the concentration of the $\mathrm{B}(\mathrm{a}) \mathrm{P}$ to which they were exposed. It was found that the longer the embryo developed, the more permeable the eggs became, taking up twice to 10 times as much $\mathrm{B}(\mathrm{a}) \mathrm{P}$ on day 25 as they did on day 1. Embryos exposed later in development were also able to excrete the metabolites of B(a)P through the egg membrane 10 times more rapidly than their counterparts which were exposed early during development. Following hatching, the larvae from those groups exposed later in development contained 2 to 5 times as much B(a)P bound to or dissolved in the tissues than did those exposed on day 1 . Hatching time was also modified by the times of exposure, with those exposed on days 15 and 25 hatching later and over a longer period of time than either the untreated or DMSO controls. Although physical abnormalities were rare, there appeared to be a consistent increase in the level of teratogenesis in those groups which were exposed early during development.
\end{abstract}

\section{INTRODUCTION}

Our inability to document accurately the cause of population declines in aquatic species is largely the result of the inaccessability of moribund individuals. Massive, sudden mortality is an exception in which we can frequently determine both the cause of the die-off as well as the source of the causative agent(s). More frequently, however, a species gradually declines in abundance and finally disappears entirely from an area in which it once flourished. There is usually no shortage of speculation to explain these declines, such as over exploitation, habitat degradation, competition with introduced species and recently even the El Niño. Hard scientific evidence however, is usually lacking. The reason for this is that the cause of such insidious mortality is greatly separated in time from the final recognizable effect - the loss of a species from its habitat.

Our interest in this subject has centred largely on the nonlethal damage produced in developing fish embryos as a result of exposures to toxic agents during various periods of their embryonic development. From these studies we have shown that fish cells in vitro 
exhibit chromosomal damage (Kocan et al., 1982), as well as developing mutations (Kocan et al., 1981) much as mammalian cells do. The chromosome damage seen in vitro has also been verified in vivo in our laboratory by Liguori ( $\mathrm{Ph}$. $\mathrm{d}$. Thesis, 1984) as well as being described under natural conditions (Longwell \& Hughes, 1980). Kligerman \& Bloom (1976) and Kligerman (1979) demonstrated chromosomal damage of a different type (SCE) and in a different species, indicating that such sublethal DNA damage is not uncommon.

In addition to physical defects observed in DNA, we have also seen changes in the capacity of trout embryos and fry to excrete xenobiotics, such as polycyclic aromatic hydrocarbons, following embryonic exposure. Biochemical alterations in enzyme function have also been reported by several investigators working with embryonic fish of different species (Binder \& Stegeman, 1980, 1983).

All of these observations suggest that sublethal exposure of fish embryos to toxic substances may result in their inability to successfully compete with normal individuals at some later period in life due to persistent sublethal damage which occurred earlier. In order to clarify some of the causes and relationships of these early biochemical alterations, we examined the dynamics of embryo development and some of the critical processes associated with early life, after the embryos were exposed to a known toxic substance. The concentrations of toxin and methods of exposure were chosen to insure experimental uniformity and consistent uptake by the eggs, and in no way were intended to duplicate natural exposures.

\section{MATERIALS AND METHODS}

\section{Experimental embryos}

Steelhead trout (Salmo gairdneri) embryos were obtained from a single female which had returned to the University of Washington experimental hatchery to spawn. Following fertilization by a single male steelhead, the eggs were maintained in lots of 100 in net egg chambers suspended in a flow-through system of dechlorinated city water at $10^{\circ} \mathrm{C}$. Temperature, water flow and chlorine were monitored continuously.

\section{Test compound}

${ }^{14} \mathrm{C}$-benzo(a)pyrene $\left({ }^{14} \mathrm{C}-\mathrm{B}(\mathrm{a}) \mathrm{P}\right)(\mathrm{Sp}$. Act. $58.5 \mathrm{mCi} / \mathrm{mMol}$ - Amersham) was diluted with unlabelled $\mathrm{B}(\mathrm{a}) \mathrm{P}$ to make a stock solution of $10 \mu \mathrm{g} / \mu \mathrm{l}$ in spectrophotometric grade dimethylsulphoxide (DMSO). This solution was used to make final exposure concentrations of $2 \mu \mathrm{g}$ and $20 \mu \mathrm{g} / \mathrm{ml}$ of water $(0.5 \% \mathrm{DMSO})$. The final activity of ${ }^{14} \mathrm{C}-\mathrm{B}(\mathrm{a}) \mathrm{P}$ was $0.23 \mu \mathrm{Ci} / \mu \mathrm{g}$.

Exposure of eggs consisted of a single 24 -h pulse at one of the above concentrations in $0.5 \mathrm{ml}$ of water per egg. Immediately following exposure each group of eggs was extensively washed in flowing water to remove any adhering $B(a) P$. A subsample of 10 ${ }^{14} \mathrm{C}-\mathrm{B}(\mathrm{a}) \mathrm{P}$ labelled eggs was removed following exposure to measure the amount of $\mathrm{B}(\mathrm{a}) \mathrm{P}$ which was taken up. Radioactivity was determined by homogenizing the entire egg and larva in a scintillation vial, adding scintillation cocktail and counting the entire amount of activity in the egg or larva on a Packard Tri Carb Liquid scintillation counter, Model 
300. When comparisons between eggs or larvae containing different amounts of pigment were being made, quenching for each system was taken into account, thus eliminating any possibility of error when comparing different types of tissue.

\section{Exposures}

Three groups of 400 eggs each were exposed to unlabelled B(a)P (Sigma, Gold Lable) on day 1, day 15, and day 25 post fertilization. Controls consisted of 600 untreated and 200 DMSO treated eggs. The three exposure periods (early, mid and late development) correspond to pre-blastula (day 1), eyed embryo (day 15), and late organogenesis (day 25), and serve to demonstrate whether the stage of development of the embryo influences the outcome of exposure to $\mathrm{B}(\mathrm{a}) \mathrm{P}$ (Fig. 1). A parallel set of 50 eggs was exposed to ${ }^{14} \mathrm{C}-\mathrm{B}(\mathrm{a}) \mathrm{P}$ in order to determine the rate of uptake of the test compound at each exposure period.

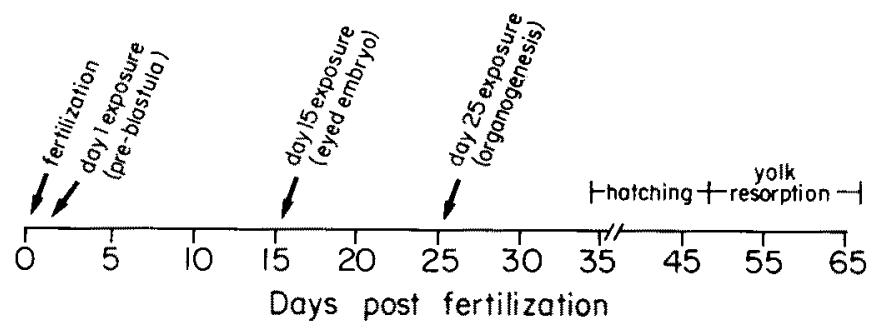

Fig. 1. Trout embryo development and benzo(a)pyrene exposure schedule. Following fertilization, eggs were allowed to water harden for $24 \mathrm{~h}$, after which they were exposed to B(a)P in water $(0.5 \%$ DMSO) for $24 \mathrm{~h}$. On days 15 and 25 post fertilization, two additional groups of eggs were similarly exposed. Eggs were sampled following each exposure period and again just prior to hatching. After hatching, sac fry (larva and yolk) were also collected for analysis and for collection of excreted water soluble metabolites of $\mathrm{B}(\mathrm{a}) \mathrm{P}$

\section{Hatching}

The effect of $\mathrm{B}(\mathrm{a}) \mathrm{P}$ on hatching was determined by recording the number of eggs which hatched each day until all eggs were hatched. Each of the treatment groups and controls consisted of four replicates of 100 eggs each. The four treatment groups were: (1) untreated controls, (2) DMSO treated controls, (3) eggs exposed one day post fertilization (pre-blastula), (4) eggs exposed 15 days post fertilization (eyed stage), and (5) eggs exposed 25 days post fertilization (late organogenesis).

\section{Metabolism/excretion}

Excretion of B(a)P metabolites was measured by two methods. One method determined the total radioactivity in each of 10 eggs sampled following exposure and washing (day 2), another 10 eggs sampled just prior to hatching (day 35), a set of $10 \mathrm{sac}$ fry sampled immediately after hatching (day 37), and 10 fingerlings sampled following total yolk resorption (day 70). By comparing the levels of ${ }^{14} \mathrm{C}-\mathrm{B}(\mathrm{a}) \mathrm{P}$ in each of these groups we could calculate the amount lost (excreted) during incubation, the amount lost 
at hatching (perivitelline fluid) and the amount present in the larva and yolk after hatching. By dissecting the larva free from the yolk we could also determine the amount present in the yolk and larva separately.

A second method of determining the amount of labelled test compound excreted by the developing eggs was to place individual eggs in small vials and cover them with a small amount of sterile water. By removing the entire volume of water three times per week and replacing it with fresh sterile water, we could determine the amount of labelled compound lost into the water every three days. The accumulated counts throughout incubation would then represent the total amount of labelled B(a)P lost from the time of exposure until hatching. In this way it was also possible to measure the amount of radioactivity released with the perivitelline fluids at the time of hatching.

This same technique of incubating in a closed system was also used to collect the excreted metabolites of sac fry during the period of yolk resorption. During yolk resorption fry were kept in a closed system where the water was collected three to four times per week and replaced with fresh sterile water. This water contained all of the excreted material from the developing larvae and was used to determine if any differences in metabolic capability had resulted from exposure of the eggs at different developmental periods.

During the collection period, water from each treatment group was placed into a dark bottle, gassed with nitrogen and frozen at $-20^{\circ} \mathrm{C}$ until it was extracted. Extractions consisted of a single hexane extraction ( 4 hexane: 1 water) followed by centrifugation at $2000 \mathrm{rpm}$ for $5 \mathrm{~min}$ to ensure that the two layers were fully separated. Following the hexane extraction the water layer was again extracted twice with ethylacetate $(4: 1)$. The hexane extraction was intended to remove any nonpolar material which might have been present and the ethylacetate to remove any slightly polar metabolites (Phase I reactants).

An aliquot of each water sample was also incubated with $\beta$-glucuronidase $(1,000$ units $/ \mathrm{ml}$ ) and sulphatase $(45$ units $/ \mathrm{ml}$ ) for $60 \mathrm{~min}$ to deconjugate any sulphate or glucuronic acid conjugates (Phase II reactants) which might be present. In this way we were able to determine the relative amount of soluble unconjugated and conjugated metabolites excreted by the various treatment groups.

\section{Teratogenesis}

From the time of hatching until the yolk was fully resorbed, the four groups of sac fry were examined three times per week until they were 60 days old. During this period all animals which appeared to be physically or behaviourally abnormal were removed and fixed in $10 \%$ formalin for future classification.

\section{RESULTS}

\section{Uptake of $\mathrm{B}(\mathrm{a}) \mathrm{P}$}

By using ${ }^{14} \mathrm{C}-\mathrm{B}(\mathrm{a}) \mathrm{P}$ it was possible to measure the amount of $\mathrm{B}(\mathrm{a}) \mathrm{P}$ entering the trout eggs at each exposure period as well as monitor for the concentration of $B(a) P$ in the exposure water. Table 1 summarizes the concentrations of $\mathrm{B}(\mathrm{a}) \mathrm{P}$ found in the eggs 
Table 1. Concentration of ${ }^{14} \mathrm{C}-\mathrm{B}(\mathrm{a}) \mathrm{P}$ in trout eggs following $24 \mathrm{~h}$ exposure

\begin{tabular}{|c|c|c|c|c|}
\hline \multirow{3}{*}{$\begin{array}{c}\begin{array}{c}\text { Exposure concen- } \\
\text { tration }(\mu \mathrm{g} / \mathrm{m} \mathrm{l})\end{array} \\
2\end{array}$} & \multirow{3}{*}{$\begin{array}{l}N \\
10\end{array}$} & \multicolumn{3}{|c|}{ Exposure day (post-fertilization) } \\
\hline & & 1 & 15 & \multirow{2}{*}{$\begin{array}{l}25 \\
59 \pm 10\end{array}$} \\
\hline & & $24 \pm 2^{*}$ & $54 \pm 10$ & \\
\hline 20 & 10 & $83 \pm 11$ & $729 \pm 123$ & $664 \pm 87$ \\
\hline \multicolumn{5}{|c|}{$\begin{array}{l}\text { Values represent nanograms (ng) of } B(a) P \text { for entire egg (i.e. yolk, embryo, chorion and } \\
\text { perivitelline fluid } \pm \text { S.D.) }\end{array}$} \\
\hline
\end{tabular}

immediately after the $24-\mathrm{h}$ exposure period. These values were used to calculate the percent loss and retention presented later in this section under "Excretion". It is evident that the newly fertilized egg is not as permeable to $B(a) P$ in the form we used for exposure, as are the more developed eggs.

The actual measured concentrations of $\mathrm{B}(\mathrm{a}) \mathrm{P}$ in the water at the start of exposure were $1.6-1.8 \mu \mathrm{g} / \mathrm{ml}$ for the $2 \mu \mathrm{g} / \mathrm{ml}$ exposure water, and $16.1-19.8 \mu \mathrm{g} / \mathrm{ml}$ for the $20 \mu \mathrm{g} / \mathrm{ml}$ exposure water. Following the $24-\mathrm{h}$ exposure, these concentrations were reduced to $1.4-1.6 \mu \mathrm{g} / \mathrm{ml}$ and $12.8-15.1 \mu \mathrm{g} / \mathrm{ml}$ : a $12 \%$ and $20 \%$ loss respectively.

\section{Excretion}

A distinct difference was observed in the rate of excretion of water soluble metabolites of $\mathrm{B}(\mathrm{a}) \mathrm{P}$ from embryos exposed early vs those exposed late in development (Fig. 2). Those exposed prior to blastula formation excrete only 2 to $3 \%$ of the total amount of $\mathrm{B}(\mathrm{a}) \mathrm{P}$ which was in the egg following exposure, while those exposed late in incubation lost as much as $20 \%$ of the total amount originally taken up during exposure. The group exposed 15 days following fertilization (eyed stage), exhibited an excretion rate midway between the early and late exposure groups. The loss of labelled B(a)P which occurred in the day 1 exposure group took place during the entire incubation period $(30+$ days), while those exposed late in development had only 10 to 15 days to excrete the $B(a) P$ prior to hatching. Considering this, the per day loss of $\mathrm{B}(\mathrm{a}) \mathrm{P}$ was even more spectacular in the late exposure group. This experiment was repeated with three separate egg lots from three different females, and the results were essentially identical each time. Likewise, the loss of soluble B(a)P from the egg was the same whether measured directly by sampling the incubation water or by measuring the difference in radioactivity inside the egg from the time of exposure until just prior to hatching. In a subsequent experiment a single batch of eggs was split into two equal lots with only one being fertilized. Both groups were exposed to ${ }^{14} \mathrm{C}-\mathrm{B}(\mathrm{a}) \mathrm{P}$ and allowed to develop for 20 days, during which eggs were sampled twice per week. At the end of the 20 days the radiation levels in the eggs from both groups was compared and found to be identical. This indicated that the small amount of compound lost from the eggs exposed early in development was not the result of embryo metabolism and excretion, since even eggs which contained no embryo lost the same small amount during the same period (i.e. $<2 \%$ ).

The amount of $\mathrm{B}(\mathrm{a}) \mathrm{P}$ in the perivitelline fluid at the time of hatching also appeared different in the early and later exposure groups. Those exposed later during develop- 


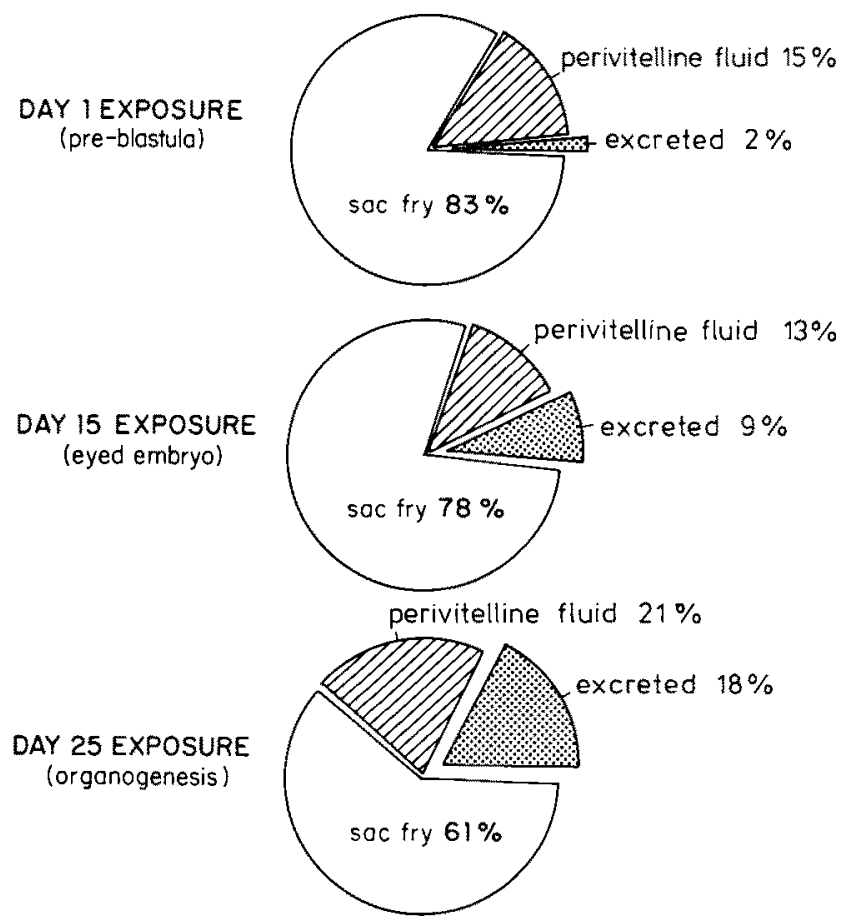

Fig. 2. Distribution of benzo(a)pyrene in trout eggs from exposure to hatching. B(a)P was identified in three components of the egg/embryo complex: (1) excretions out of the egg during embryo development up to the time of hatching: (2) losses along with perivitelline fluid at the time of hatching; (3) a component bound to or dissolved in the embryo/yolk. Embryos exposed later in development excreted considerably more of their $\mathrm{B}(\mathrm{a}) \mathrm{P}$ content than did those exposed early. Conversely, the amount present in the embryo/yolk was about $25 \%$ greater in the early exposure group than in the late exposure group. Embryos exposed midway through development exhibited intermediate values in all three categories

ment again released more labelled compound at the time of hatching than did those exposed early.

Sac fry continued to excrete labelled soluble compounds into the water throughout yolk resorption. Once the yolk was totally resorbed and the abdominal suture line closed ( 30 to 45 days post hatching), no label could be detected in the water in which the fry were kept.

\section{Hatching}

Both day 15 and day 25 exposures of trout eggs to $\mathrm{B}(\mathrm{a}) \mathrm{P}$ resulted in differences in the hatching dynamics when compared to the untreated and DMSO controls. Table 2 summarizes the hatching data from the 6 treatment groups and the controls. Eggs which were exposed early in development exhibited no statistical difference in hatching times when compared to the controls. Those eggs exposed later in development began hatching later than either the early exposure group or the controls, and took about 3 days longer to hatch than either of the other groups. No difference in hatching success was 
Table 2. Mean hatching day of steelhead trout eggs treated with benzo(a)pyrene on days 1,15 and 25 post fertilization

\begin{tabular}{|c|c|c|c|c|c|}
\hline $\begin{array}{l}\text { Exposure day } \\
\text { (post- } \\
\text { fertilization) }\end{array}$ & $\begin{array}{c}\text { Exposure } \\
\text { concentration } \\
(\mu \mathrm{g} / \mathrm{ml})\end{array}$ & $\begin{array}{c}\text { Mean day to } \\
50 \% \text { hatch } \\
( \pm \text { S.D. })\end{array}$ & $\mathrm{P}<{ }^{\circ}$ & $\begin{array}{l}\text { Mean day to } \\
90 \% \text { hatch } \\
\text { ( } \pm \text { S.D.) }\end{array}$ & $\mathrm{P}<{ }^{\circ}$ \\
\hline $\begin{array}{c}\text { Untreated } \\
\text { control }\end{array}$ & - & $39.8 \pm 1.47$ & - & $43.0 \pm 2.37$ & - \\
\hline $\begin{array}{l}\text { DMSO } \\
\text { control }\end{array}$ & $(0.5 \%)$ & $39.4 \pm 1.14$ & NS & $41.6 \pm 0.89$ & NS \\
\hline 1 & $\begin{array}{r}2 \\
20\end{array}$ & $\begin{array}{l}39.8 \pm 2.98 \\
39.0 \pm 2.16\end{array}$ & $\begin{array}{l}\text { NS } \\
\text { NS }\end{array}$ & $\begin{array}{l}43.3 \pm 4.72 \\
42.5 \pm 3.11\end{array}$ & $\begin{array}{l}\text { NS } \\
\text { NS }\end{array}$ \\
\hline 15 & $\begin{array}{r}2 \\
20\end{array}$ & $\begin{array}{l}43.0 \pm 1.41 \\
43.0 \pm 2.31\end{array}$ & $\begin{array}{l}.01 \\
.01\end{array}$ & $\begin{array}{l}47.5 \pm 2.38 \\
47.3 \pm 3.30\end{array}$ & $\begin{array}{l}.01 \\
.05\end{array}$ \\
\hline 25 & $\begin{array}{r}2 \\
20\end{array}$ & $\begin{array}{l}43.5 \pm 3.32 \\
41.8 \pm 0.96\end{array}$ & $\begin{array}{l}.05 \\
.05\end{array}$ & $\begin{array}{l}47.3 \pm 3.30 \\
45.5 \pm 1.73\end{array}$ & $\begin{array}{l}.05 \\
.05\end{array}$ \\
\hline
\end{tabular}

noted as a result of exposure to $\mathrm{B}(\mathrm{a}) \mathrm{P}$, even though some eggs were exposed to concentrations as high as $20 \mu \mathrm{g} / \mathrm{ml}$, a concentration about 1000 times greater than would naturally be encountered. Both $\mathrm{B}(\mathrm{a}) \mathrm{P}$ concentrations produced the same hatching pattern in their respective treatment group.

\section{Yolk and larval tissue}

Comparison of the amount of labelled compound present in yolk and larval tissue at the time of hatching showed that the yolk contained the majority of the original egg content of labelled $\mathrm{B}(\mathrm{a}) \mathrm{P}$. Table 3 summarizes the percent distribution of radioactivity

Table 3. Concentration of $\mathrm{B}(\mathrm{a}) \mathrm{P}$ in embryo and yolk immediately post hatching

\begin{tabular}{|c|c|c|c|c|c|c|}
\hline \multicolumn{2}{|c|}{$\begin{array}{c}\text { Exposure } \\
\text { concentration } \\
(\mu \mathrm{g} / \mathrm{ml})\end{array}$} & $N$ & \multicolumn{4}{|c|}{ Exposure day (post-fertilization) } \\
\hline \multirow{3}{*}{2} & \multirow{3}{*}{$\begin{array}{l}\text { Embryo } \\
\text { Yolk }\end{array}$} & & 1 & 15 & & 25 \\
\hline & & 5 & $1.3 \pm 0.2^{*}(6 \%)^{* *}$ & $3.7 \pm 1.4(9 \%)$ & 5.7 & $\pm 3.0(16 \%)$ \\
\hline & & 5 & $19 \pm 2.1(94 \%)$ & $38 \pm 9.9(91 \%)$ & 31 & $\pm 2.5(84 \%)$ \\
\hline \multirow{2}{*}{20} & Embryo & 5 & $5.0 \pm 1.3(10 \%)$ & $18 \pm 3.2(9 \%)$ & 26 & $\pm 4.5(22 \%)$ \\
\hline & Yolk & 5 & $44 \pm 3.9(90 \%)$ & $183 \pm 33 \quad(91 \%)$ & 93 & $\pm 30 \quad(78 \%)$ \\
\hline \multicolumn{7}{|c|}{$\begin{array}{l}\text { Values represent nanograms (ng) of } B(a) P \text { bound to or dissolved in embryonic tissues or yolk } \\
( \pm S . D .) \\
\text { Values in ( ) represent \% of } B(a) P \text { in larvae or yolk relative to the total amount of } B(a) P \text { in } \\
\text { larva }+ \text { yolk (sac fry) at hatching }\end{array}$} \\
\hline
\end{tabular}


levels detected in yolk and larval tissue at the time of hatching. It is apparent from these data that those embryos which were exposed earlier during incubation and excreted less $\mathrm{B}(\mathrm{a}) \mathrm{P}$ than did those exposed later, retained the extra labelled material in the yolk (90 to $94 \%$ ) as compared to those exposed on day 25 which retained much less ( 78 to $84 \%$ ). From this it is apparent that the larvae which were exposed early accumulate more $\mathrm{B}(\mathrm{a}) \mathrm{P}$ in their tissues at the time of hatching than those exposed later in development. By the time the yolk had been fully resorbed the fry from each exposure group contained the same level of bound ${ }^{14} \mathrm{C}$, regardless of the time of their exposure.

\section{Metabolism/excretion}

Table 4 summarizes the results of organic extractions of waters in which sac fry from the various exposure groups were held until they had fully resorbed their yolk material. It is apparent that both slightly polar and conjugated forms of $\mathrm{B}(\mathrm{a}) \mathrm{P}$ metabolites were excreted into the water. The large amount of labelled material which remained in the

Table 4. Percent water soluble ${ }^{14} \mathrm{C}-\mathrm{B}(\mathrm{a}) \mathrm{P}$ excreted by sac fry

\begin{tabular}{|lccc|}
\hline \multicolumn{1}{|c|}{ Extraction procedure * } & Exposure day (post-fertilization) \\
\hline & 1 & 15 & 25 \\
Hexane $(4: \mathbf{1})$ & 90 & 93 & 97 \\
Ethylacetate $(4: 1)$ & 71 & 63 & 35 \\
Ethylacetate $(\boldsymbol{\beta}$-Glucuronidase/sulphatase) & 52 & 43 & 36 \\
Extractions done on water collected daily from 10 sac fry from each treatment group over a \\
5-day period
\end{tabular}

water following organic extraction and $\beta$-glucuronidase/sulphatase deconjugation may represent glutathione conjugates of $\mathrm{B}(\mathrm{a}) \mathrm{P}$ metabolites.

There appears to be a relationship between the time of exposure during development and the amount of soluble metabolites subsequently excreted by the larva during yolk resorption, with those exposed later excreting larger quantities of soluble and conjugated material. By the time the yolk is fully resorbed, however, all of these differences disappear. Both exposure groups $(2 \mu \mathrm{g}$ and $20 \mu \mathrm{g})$ exhibited the same patterns of solubility.

\section{Teratogenesis}

Among the control fish (unexposed and DMSO treated), less than $1 \%$ of the 600 animals exhibited any type of physical defect by the time they had totally resorbed their yolk. The treated groups, however, all showed increased physical defects by this time with the majority appearing in those animals treated early during their development. Table 5 summarizes the data from the teratogenesis evaluation.

The majority of defects represented in this experiment were ocular abnormalities, cephalic deformity, spinal deformity and fin reductions or eliminations. 
Table 5. Teratogenic effects on fish embryos following exposure to benzo(a)pyrene.

\begin{tabular}{|cccc|}
\hline $\begin{array}{c}\text { B(a)P } \\
\text { concentration }\end{array}$ & No. exposed & $\begin{array}{c}\text { Post-fertilization } \\
\text { Exposure time }\end{array}$ & $\begin{array}{c}\text { \% abnormal at } \\
\text { hatching }\end{array}$ \\
\hline $2 \mu \mathrm{g} / \mathrm{ml}$ & 100 & day 1 & 6 \\
$2 \mu \mathrm{g} / \mathrm{ml}$ & 100 & day 25 & 1 \\
$2 \mu \mathrm{g} / \mathrm{ml}$ & 230 & day 1 & 5 \\
$2 \mu \mathrm{g} / \mathrm{ml}$ & 340 & day 15 & 3 \\
$20 \mu \mathrm{g} / \mathrm{ml}$ & 290 & day 1 & 13 \\
$20 \mu \mathrm{g} / \mathrm{ml}$ & 280 & day 15 & 11 \\
$20 \mu \mathrm{g} / \mathrm{ml}$ & 280 & day 25 & 4 \\
normal/DMSO & 300 & day 1 & $<1$ \\
normal/DMSO & 300 & day 25 & \\
Day $1=$ pre-blastula; day $15=$ eyed stage (1st eye pigment); day 25 = late organogenesis; day \\
35 hatching
\end{tabular}

\section{DISCUSSION}

Unlike infectious diseases, genetic and metabolic diseases are usually detectable only when comparative measurements can be made from a single individual, and a well established normal baseline for those measurements is available for comparison.

The data we have presented here demonstrate that dramatic nonlethal deviations from the norm can occur in embryos following exposure to a known environmental contaminant. Since no significant mortality occurred in the test animals, and precise measurements were needed on large numbers of individuals with similar genetic background, it is unlikely that these same changes would have been detectable under natural conditions. It is not clear what effect each of the alterations we observed would have on the survival and reproductive potential of the exposed population. Based on what is known of some of the enzyme systems which were altered, there presumably could be dramatic effects at some later period in the organism's development.

It has been well established that trout as well as other fish species have active mixed function oxygenase (MFO) and aryl hydrocarbon hydroxylase (AHH) systems (Bend \& James, 1978; Iwaoka et al., 1979; Pederson et al., 1976), although the level of activity varies by species. This subject is extensively reviewed by Stegeman (1981). Since these enzymes function both to eliminate certain environmental contaminants as well as endogenous steroids, their alteration could pose serious problems to the organism. The mechanism(s) underlying the altered excretory patterns we have observed have not been worked out for fish, although they have been examined in several mammalian systems (Lucier, 1981). It is not unlikely that there are similar counterparts in fish. One possibility is that exposure of the embryo in the pre-blastula stage results in an inhibition or repression of the MFO or conjugation systems, thereby reducing the capacity of the embryo and fry to quickly metabolize and excrete many xenobiotics. Alternatively, the presence of a functional embryo with most of its organs and enzyme systems intact at the time of exposure (organogenesis) could result in the induction of these systems (Binder \& 
Stegeman, 1983$)$, thereby increasing the capacity of the organism to excrete the foreign compound. Those embryos which were exposed as a pre-blastula would encounter $\mathrm{B}(\mathrm{a}) \mathrm{P}$ only via the yolk, which is being resorbed, and possibly not respond the same as those which received total body exposure. Another possibility is that different responses result from early and late exposures, thus causing each to respond differently than would an unexposed embryo. Whichever the case, if these differences in metabolic processing and excretion of B(a)P persist into later life, they could alter the organism's ability to deal with subsequent exposure to similar compounds and its ability to process endogenous compounds such as steroids.

As we have pointed out, the age of an embryo at the time of exposure to a xenobiotic influences the ultimate capacity of the later larva to excrete that compound during yolk resorption. Those exposed early excrete the compound more slowly than those exposed later in development. Whether rapid elimination of xenobiotics is desirable or not depends on whether the reduction in body burden of the chemical outweighs the rapid formation of activated intermediate compounds which have the capacity to bind to protein and nucleic acid and thereby to alter enzyme function, DNA stability, and initiate neoplasia.

Sinnhuber \& Wales (1974) and Wales et al. (1978) observed that the embryo's age at the time of exposure to aflatoxin influenced the development of tumors later in life. This could be explained by different rates of metabolism and excretion by the different ages of the embryos at the time of exposure.

It is clear that differences in body burden, excretory rate and the form of the conjugated compounds extends beyond hatching and through yolk resorption. It has yet to be demonstrated, however, whether these differences persist when the organism is exposed to similar compounds as it matures, or whether these enzymatic alterations ultimately affect the individual through behavioural modification or hormonal imbalances (Lorz et al., 1979).

The changes we observed in hatching dynamics may likewise be related to alterations in enzyme systems which partially control hatching. It has been well established (Blaxter, 1969) that hatching enzymes are responsible for the onset of hatching and egg membrane disruption. It is also known that a variety of environmental factors, including pollution, can alter these enzymes and affect the hatching dynamics of a species. Therefore, if polycyclic aromatics such as $\mathrm{B}(\mathrm{a}) \mathrm{P}$ can alter hatching gland enzymes, it could explain the changes we observed.

Teratogenic abnormalities are relatively rare in non-inbred trout, but appear to increase as a result of exposure to $B(a) P$. The more obvious teratogenic effects which we observed in the treated groups, would probably lead to the death of the affected individuals in their natural habitat through starvation and/or predation. It is likely that a number of individuals with only minor defects escape detection, but would ultimately be lost from the population due to behavioural anomalies and associated physical defects. As Laale points out (1981), the developing fish embryo is a sensitive organism which responds to changes in its environment, including chemical pollution. Skeletal and cephalic abnormalities of newly hatched fish, which we encountered most frequently, are believed by some to result from genetic alterations (Schröder, 1969, 1973; and Nelson, 1977), which can result from exposure to B(a)P and other polycyclic aromatic hydrocarbons. Hose et al. $(1981,1982)$ showed that developing flatfish eggs exposed to 
B(a)P often suffered from developmental abnormalities as did those embryos produced by females which had been exposed to B(a)P prior to egg laying.

Although infectious diseases are a significant factor influencing the health and survival of aquatic organisms, there is a more insidious form of disease which results from exposure to sublethal toxic substances in the environment. Those organisms which are exposed, any time from fertilization to sexual maturity, run the risk of becoming genetically damaged, and thereby being less fit to respond to other forms of environmental insults, and more seriously, having a reduced capacity to produce normal healthy offspring. Effects such as induction and/or suppression of existing enzyme systems during embryonic development also pose the threat of compromising an individual's ability to cope with later exposure to environmental contaminants.

Acknowledgements: This work was supported in part by grants from the NIEHS (ES-02190-02), EPA (R-810057-1), NOAA (OMPA-NA 80 RAD 00053) and NOAA (MESA-04-78-B01-13). The authors also acknowledge the assistance of $\mathrm{K}$. Sabo, V. Liguori and L. Ginno.

\section{LITERATURE CITED}

Bend, J. R. \& James, M. O., 1978. Xenobiotic metabolism in marine and freshwater species. In: Biochemical and biophysical perspectives in marine biology. Ed. by D. C. Malins \& J. R. Sargent. Acad. Press, New York, 4, 128-132.

Binder, R. L. \& Stegeman, J. J., 1980. Induction of aryl hydrocarbon hydroxylase activity in embryos of an estuarine fish. - Biochem. Pharmac. 29, 949-951,

Binder, R. L. \& Stegeman, J. J., 1983. Basal levels and induction of hepatic aryl hydrocarbon hydroxylase activity during the embryonic period of development in brook trout. - Biochem. Pharmac. 32, 1324-1327.

Blaxter, J. H. S., 1969. Development: Eggs and larvae. In: Fish physiology. Ed. by W. S. Hoar \& D. J. Randall. Acad. Press, New York, 3, 178-252.

Hose, J, E., Hannah, J. B., Landolt, M. L., Miller, B. S., Felton, S. P. \& Iwaoka, W. T., 1981. Uptake of benzo(a)pyrene by gonadal tissue of flatfish (pleuronectidae) and its effects on subsequent egg development. - J. Toxicol. environ. Hith 7, 991-1000.

Hose, J. E., Hannah, J. B., DiJulio, D., Landolt, M. L., Miller, B. S., Iwaoka, W. T. \& Felton, S. P., 1982. Effects of benzo(a)pyrene on early development of flatfish. - Archs environ. Contam. Toxicol. 11, 167-171.

Iwaoka, W. T., Landolt, M. L., Pierson, K. B., Felton, S. P. \& Abolins, A., 1979. Studies on aryl hydrocarbon hydroxylase, polycyclic hydrocarbon content and epidermal tumors of flatfish. In: Animals as monitors of environmental pollutants. Ed. by S. W. Nielsen, G. Migaki \& D. G. Scarpelli. Natn. Acad. Sci., Washington, 85-93.

Kligerman, A. D., 1979. Induction of sister chromatid exchanges in the central mudminnow following in vivo exposure to mutagenic agents. - Mutat. Res. 64, 205-217.

Kligerman, A. D. \& Bloom, S. E., 1976. Sister chromatid differentiation and exchanges in adult mudminnows (Umbra limi) after in vivo exposure to 5-bromodeoxyuridine. - Chromosoma 56, 101-109.

Kocan, R. M., Landolt, M. L., Bond, J. \& Benditt, E. P., 1981. In vitro effect of some mutagens/ carcinogens on cultured fish cells. - Archs environ. Contam. Toxicol. 10, 663-671.

Kocan, R. M., Landolt, M. L. \& Sabo, K. M., 1982. Anaphase aberrations: A measure of genotoxicity in mutagen-treated fish cells. - Environ. Mutagen. 4, 181-189.

Laale, H. W., 1981. Teratology and early fish development. - Am. Zool. 21, 517-533.

Longwell, A. C. \& Hughes, J. B., 1980. Cytologic, cytogenetic and developmental state of Atlantic mackerel eggs from sea surface waters of New York Bight, and prospects for biological effects monitoring with ichthyoplankton. - Rapp. P.-v. Réun. Cons. int. Explor. Mer. 179, 275-291.

Lorz, H. W., Glenn, S. W., Williams, R. H., Kunkel, C. M., Norris, L. A. \& Loper, B. R., 1979. Effects of 
selected herbicides on smolting of coho salmon. U.S. Environmental Protection Agency, Corvallis, Oregon (Prepubl. Rep.).

Lucier, G. W., 1981. Developmental aspects of drug conjugation. In: Developmental toxicology. Ed. by C. A. Kimmell \& J. Buelke-Sam. Raven Press, New York, 101-114.

Nelson, J. S., 1977. Evidence of genetic basis for absence of the pelvic skeleton in brook stickleback, Culaea inconstans, and notes on the geographical distribution and origin of the loss. - J. Fish. Res. Bd Can. 34, 1314-1320.

Pederson, M. G., Hershberger, W. K., Zachariah, P. K. \& Juchau, M. R., 1976. Hepatic biotransformation of environmental xenobiotics in six strains of rainbow trout (Salmo gairdneri). - J. Fish. Res. Bd Can. 33, 666-675.

Schröder, J. H., 1969. Inheritance of radiation-induced spinal curvatures in the guppy, Lebistes reticulatus. - Can. J. Genet. Cytol, 11, 937-947.

Schröder, J. H., 1973. Teleosts as a tool in mutation research. In: Genetics and mutagenesis of fish. Ed. by J. H. Schröder. Springer, Berlin, 91-99.

Sinnhuber, R. O. \& Wales, J. H. 1974. Aflatoxin $B_{1}$ hepatocarcinogenicity in rainbow trout embryos. - Fedn Proc. Fedn Am. Socs exp. Biol. 33, 247.

Stegeman, J. J., 1981. Polynuclear aromatic hydrocarbons and their metabolism in the marine environment. In: Polycyclic hydrocarbons and cancer. Ed. by H. V. Gelboin \& P. O. P. Ts'o. Acad. Press, New York, 3, 1-60.

Wales, J. H., Sinnhuber, R. O., Hendricks, J. D., Nixon, J. E. \& Eisele, T. A., 1978. Aflatoxin $B_{1}$ induction of haepatocellular carcinoma in the embryos of rainbow trout (Salmo gairdneri). $-\mathrm{J}$. natn. Cancer Inst. 60, 1133-1137. 